\title{
Knowledge, Attitudes, And Practices Towards COVID-19 Among Mizan-Aman Town Residents In SNNPR, Bench Shako Zone, Southwest Ethiopia, 2020
}

\author{
Aklilu Mamo Dachew ( $\square$ abigiaakmamo@gmail.com ) \\ Mizan Tepi University https://orcid.org/0000-0003-3862-695X \\ Girma Mamo Zegene \\ mizan aman health science collage \\ Wasihun Adraro Ambo \\ mizan amnan health science collage \\ Meseret Gebremariam Setegn \\ mizan aman health science collage
}

Research

Keywords: Knowledge, Attitude, Practice, COVID-19, Mizan-Aman

Posted Date: February 2nd, 2021

DOl: https://doi.org/10.21203/rs.3.rs-159253/v1

License: (c) (i) This work is licensed under a Creative Commons Attribution 4.0 International License.

Read Full License 


\section{Abstract}

Back ground: The first case of COVID 19 in Ethiopia was confirmed on March 13, 2020. Currently the disease is highly spreading into almost all administrative regions of Ethiopia. COVID -19 is not only a health problem but also causes to the socio-economic crisis.

Methods ; community based descriptive study design was conducted in Mizan aman town. Three kebeles were randomly selected from the five kebeles, by proportionally allocating the samples, to each kebeles, from shesheka 134, from Adiss ketema 166, from Kometa ketema, 122 samples taken. Households from each kebele were selected by systematic random sampling. First house was selected randomly and every 12th house was selected for the study and one participant from each house was taken for interview by lottery method. Data were collected by using a structured questionnaire adapted from different literatures. Data collectors used interview methods by strictly using masks and keeping physical distances.Questionaire administered data collection was avoided during data collection time to reduce cross contamination. Data was entered in EpiData version 3.1 and exported to SPSS version 21 for analysis. Descriptive analysis was done to summarize the frequencies of correct and percentages. Variables whose $p$-value $<0.05$ were considered as statistically significant

Result The percentage of the respondents who correctly answered fever, fatigue, dry cough and muscle ache can be one of the symptoms of COVID 19 was $94.9 \%$ and $74.8 \%$ of the respondents correctly answered that, stuffy nose, runny nose, and sneezing are additional symptoms of corona virus. According to the finding, $64.3 \%$ had confidence that Ethiopia can win the battle and the study participants who had optimistic attitude weather they go quarantine if infected was $70.6 \%$. The study result showed that $64.3 \%$ visited the crowded place during the interview and $61.1 \%$ didn't wear masks when leaving home, $50.8 \%$ of the respondents did not avoid cultural behaviors, such as shaking hands, only $48.4 \%$ have been practiced social distancing.

\section{Background}

COVID-19 is a pandemic, emergency respiratory disease which is caused by a novel coronavirus and was first detected in December 2019 in Wuhan, China. The disease is highly contagious, and its main clinical symptoms include fever, dry cough, fatigue, myalgia, and dyspnea. In China, patients with COVID-19, developed acute respiratory distress syndrome, septic shock, difficulty in metabolic acidosis, bleeding and coagulation dysfunction[1].

In January 2020, the first US case was reported in Washington State and by the end of March and US became the center of the pandemic accounting for the most reported cases worldwide. While New York city was attacked by COVID-19 with highest number of cases, that obligated to enforce the social distancing guidelines with news reports outlining the rapid spread to most US cities[2]. The COVID-19 pandemic occurred as a massive global health crisis. Until this research was conducted the top affected 
countries in the world were US America, Brazil and Spain Similarly in Africa,S. Africa and Egypt taking the first line in number of total cases [3].

World Health Organization (WHO) had predicted that the pandemic may kill between 83,000 and 190,000 people in African countries in the first year, depending on governments' responses. Normally COVID-19 pandemic mitigation strategies for developing countries are similar with developed countries ,but the health facilities arrangement are absolutely different than developed nations [4]. But some African countries also have a wealth of relevant lessons from dealing with previous HIV/AIDS and Ebola epidemics by involving communities[5].

The pandemic impact is multi-dimensional and varied in its severity and peoples vulnerabilities. The Africa Centre for Disease Control and Prevention (African CDC) is planning the region's capacities by affording testing technologies, promoting community involvement on COVID 19 pandemic management, and social supporting [4].

The immediate health impact is directly observed, but the indirect consequences beyond health not easily understood. These include food insecurity, other chronic health follow-ups, unemployment, lack of regular social interactions, and shortage of personal protective equipment[6].

The first case of COVID - 19 in Ethiopia was confirmed on March 13, 2020. The case was a Japanese man reported to have traveled from Japan to Burkina Faso and who then arrived in Ethiopia. Latter on July 2020, the number of new cases and deaths were insignificant but from July to August this number dramatically increased and reached above 1000 cases and above 10 deaths per day [7]. By the state of emergency, even though strict measures are being implemented to control the rapid spread of the ongoing COVID-19 by Ethiopian government, these measures will be effective if People's knowledge, attitudes, and practices is measured and correction methods are implemented. Because the only method to control COVID-19 is applying WHO prevention measure [8],assessing and understanding knowledge, attitude and practice of the communities is very significant.

In order to strengthen COVID-19 outbreak management, screening and testing shall be an urgent besides KAP assessment. Since Corona virus is newly arisen and promptly spreading, researches are not done in the communities' awareness, attitude and practice Mizan -Aman town,[9].

As a base line data, findings about Knowledge, Attitude and Practice of peoples towards COVID-19 helps to preventive activities and improve misconceptions and avoiding unnecessary fears [10].

Therefore this study was aimed to assess the knowledge, attitude and practice of Mizan Aman town communities.

The study will be a base line data for the government for controlling the pandemic by pinpointing the gaps in the community. In addition it will be strengthening instrument for government's effort to control COVID 19 dissemination. 


\section{Methods}

\section{Study area and design}

The community based cross-sectional survey was carried out with in the state of emergency for COVD -19 prevention in Ethiopia at Mizan Aman town in SNNPR Bench Shako zone from June 30/2020 to July 20/2020, The town was located at $561 \mathrm{~km}$ far from the capital city of Ethiopia, Addis Ababa towards southwest with a total population of 57,537 of those 30,379 were males and 27,158 females (CSA, 2007). There are five kebeles in the town these kebeles are Hibret,Adis ketema,Edget, Kometa and Shashaka.

\section{Sample size and sampling technique}

Sample size was determined by using single population proportion formula by assuming $95 \%$ confidence interval, $5 \%$ margin of error with $\mathrm{P}=50 \%$.

$$
\boldsymbol{n}=\frac{\left.(Z a / 2)^{2}\right) * \mathbf{p}(1-p)}{d^{2}}
$$

$\mathrm{n}=\left[(1.96)^{2}(0.5)(1-0.5)\right] /(0.05)^{2} \rightarrow \mathrm{n}=384$

BY adding 10\% non-response rate $\rightarrow 422 \mathrm{HHs} .7696 .0 .055$

SAPLING TECNIQUE

Three kebeles were randomly selected from the five kebeles, which were shesheka, Addis ketema and Kometa. Shesheka has 2454 households and Addis ketema has 3021 households Kometa kebele has 2221 households, by proportionally allocating the samples, to each kebeles,

For shesheka $=422 / 7696 * 2454=134$

For adiss ketema $=0.055 * 3021=166$

For Kometa ketema $=.055 * 2221=122$

Households from each kebele were selected by systematic random sampling,

$\mathrm{K}$ was calculated as 7696/422 $=12$ the first house was selected randomly and every 12 th $\mathrm{HH}$ was selected for the study and one participant from each $\mathrm{HH}$ was taken for interview by lottery method.

\section{Data collection tools and methods}


Data were collected by using a structured questionnaire adapted from different literatures $(1,12.13)$. The questionnaire had two sections; the first section was Sociodemographic dimension and the second section covered assessment of knowledge, attitude and practice towards COVID 19. The knowledge assessment had 12 questions: 4 regarding clinical sign and symptoms (K1-K4), 3 regarding transmission routes (K5-K7), and 5 regarding prevention and control (K8-K12) of COVID-19. These questions were assessed by using "yes", "no" "I am not sure "option. The total knowledge score ranged from 0 to 12, with above the mean score denoting as good knowledge of COVID-19.Similarly there were 6 attitude questions answered as "agree", "not agree" and "I am not sure". The attitude status measuring questions also stated as optimistic and not pessimistic. The last 6 questions were practice questions answered by "yes" and "no". Data collectors used interview methods by strictly using masks and keeping physical distances.Questionaire administered data collection was avoided during data collection time to reduce cross contamination.

\section{Statistical data analysis}

Data was entered in EpiData version 3.1 and exported to SPSS version 21 for analysis. Descriptive analysis was done to summarize the frequencies of correct and percentages. Variables whose $p$-value $<0.05$ were considered as statistically significant.

\section{Results}

\section{Background characteristics of respondents}

Out of 420 respondents, 409 agreed to give their interview which was $97.4 \%$ response rate. Two hundred fifty one; $251(61.4 \%)$ participants were males. The mean age of the respondents was $30( \pm 12)$ years. Majority of the respondents; $190(46.5 \%)$ were Christian orthodox followed by protestant 136 (33.3\%). Almost half $214(52.3 \%)$ of respondents were married and many $121(29.6 \%)$ of them had collage level educational experiences. About $133(32.5 \%)$ were merchants. (Table 1) 
Table 1

Sociodemographic characteristics of the respondent in Mizan Aman town south west Ethiopia July $2020(n=409)$

\begin{tabular}{|c|c|c|c|}
\hline \multicolumn{2}{|l|}{ Characteristics } & \multirow{2}{*}{$\begin{array}{l}\text { Frequency } \\
251\end{array}$} & \multirow{2}{*}{$\begin{array}{l}\text { Percent (\%) } \\
61.4\end{array}$} \\
\hline Sex & Male & & \\
\hline & Female & 158 & 38.6 \\
\hline \multirow[t]{5}{*}{ Age } & $<=19$ & 55 & 13.4 \\
\hline & $20-29$ & 209 & 51.1 \\
\hline & $30-39$ & 89 & 21.8 \\
\hline & $40-49$ & 27 & 6.6 \\
\hline & $>=50$ & 29 & 7.1 \\
\hline \multirow[t]{5}{*}{ Marital status } & Never married & 159 & 38.9 \\
\hline & Married & 214 & 52.3 \\
\hline & Divorced & 24 & 5.9 \\
\hline & Widowed & 4 & 1.0 \\
\hline & Cohabitation & 8 & 2.0 \\
\hline \multirow[t]{5}{*}{ Religion } & Orthodox & 190 & 46.5 \\
\hline & Muslim & 47 & 11.5 \\
\hline & Protestant & 136 & 33.3 \\
\hline & Catholic & 5 & 1.2 \\
\hline & Other & 31 & 7.6 \\
\hline \multirow[t]{5}{*}{ Educational status } & Never read & 23 & 5.6 \\
\hline & Primary & 70 & 17.1 \\
\hline & Secondary & 117 & 28.6 \\
\hline & College & 121 & 29.6 \\
\hline & University & 78 & 19.1 \\
\hline \multirow[t]{4}{*}{ Occupational status } & Merchant & 133 & 32.5 \\
\hline & Government & 109 & 26.7 \\
\hline & NGO & 7 & 1.7 \\
\hline & Student & 101 & 24.7 \\
\hline
\end{tabular}




\begin{tabular}{|llll|}
\hline Characteristics & Frequency & Percent (\%) \\
\hline & Unemployed & 59 & 14.4 \\
\hline
\end{tabular}

\section{Respondents' knowledge Status about COVID 19}

\section{Towards symptoms of the disease}

The majority of respondents showed high level of knowledge about the respiratory symptoms of the disease and 388 (94.9\%) reported that fever, fatigue, Dry cough and muscle ache can be one of the symptoms, 306 (74.8\%) of the respondents were also reported that, stuffy nose, runny nose, and sneezing are additional symptoms of corona virus 2019, (Table 2).

\section{Towards disease transmission}

Of all the interviewees $307(75.1 \%)$ knew that the disease is transmitted through contacting or eating wild animals. In contrary to this $63(15.4 \%)$ responded that contacting or eating wild animals do not transmits COVID 19 and 39 (9.5\%) are neutral . on the other hand 338 (82.6\%) believed that the disease transmission can occur through respiratory droplets, (Table 2).

\section{Towards disease prevention measures}

The majority of interviewees had good knowledge about most of the preventive measures that can help in limiting the disease transmission, $365(89.2 \%)$ of respondents believe wearing general medical mask for ordinary people for preventing disease and $277(67.7 \%)$ also reported not going in crowded environment is preventive measures too, table 2 .

\section{Towards disease treatment}

The majority 390 (95.4\%) of respondents believed that isolation and supportive treatment of people who are infected with the COVID-19 virus is the best way of mitigating the pandemics, (Table 2). 
Table 2

knowledge status towards COVID 19 among Mizan Aman town residents in south west Ethiopia, July $2020(n=409)$

\begin{tabular}{|c|c|c|c|}
\hline Variables & Responses & Frequency & $\begin{array}{l}\text { Percent } \\
(\%)\end{array}$ \\
\hline \multirow{3}{*}{$\begin{array}{l}\text { The main sign and symptom of COVID } 19 \text { are fever, fatigue, } \\
\text { dry cough and muscle ache. }\end{array}$} & Yes & 388 & 94.9 \\
\hline & No & 15 & 3.7 \\
\hline & $\begin{array}{l}\text { I don't } \\
\text { know }\end{array}$ & 6 & 1.5 \\
\hline \multirow{3}{*}{$\begin{array}{l}\text { Unlike the common cold, stuffy nose, runny nose, and } \\
\text { sneezing are less common in COVID } 19 .\end{array}$} & Yes & 84 & 20.5 \\
\hline & No & 306 & 74.8 \\
\hline & $\begin{array}{l}\text { I don't } \\
\text { know }\end{array}$ & 19 & 4.6 \\
\hline \multirow{3}{*}{$\begin{array}{l}\text { Eating raw meat or contacting wild animals will exposed to } \\
\text { COVID } 19\end{array}$} & Yes & 307 & 75.1 \\
\hline & No & 63 & 15.4 \\
\hline & $\begin{array}{l}\text { I don't } \\
\text { know }\end{array}$ & 39 & 9.5 \\
\hline \multirow{3}{*}{$\begin{array}{l}\text { All infected persons with COVID } 19 \text { may not develop to severe } \\
\text { condition }\end{array}$} & Yes & 365 & 89.2 \\
\hline & No & 29 & 7.1 \\
\hline & $\begin{array}{l}\text { I don't } \\
\text { know }\end{array}$ & 15 & 3.7 \\
\hline \multirow{3}{*}{$\begin{array}{l}\text { Persons with COVID- } 19 \text { cannot transmit the virus to others } \\
\text { when a fever is not present }\end{array}$} & Yes & 132 & 32.3 \\
\hline & No & 258 & 63.1 \\
\hline & $\begin{array}{l}\text { I don't } \\
\text { know }\end{array}$ & 19 & 4.6 \\
\hline \multirow{3}{*}{$\begin{array}{l}\text { The COVID } 19 \text { virus can spreads via respiratory droplets from } \\
\text { infected individuals }\end{array}$} & Yes & 338 & 82.6 \\
\hline & No & 62 & 15.2 \\
\hline & $\begin{array}{l}\text { I don't } \\
\text { know }\end{array}$ & 9 & 2.2 \\
\hline \multirow{3}{*}{$\begin{array}{l}\text { It is not necessary to aware children and young to take } \\
\text { measures to prevent disease }\end{array}$} & Yes & 108 & 26.4 \\
\hline & No & 290 & 70.9 \\
\hline & $\begin{array}{l}\text { I don't } \\
\text { know }\end{array}$ & 11 & 2.7 \\
\hline $\begin{array}{l}\text { Currently there is no effective cure for COVID } 19 \text {, but early } \\
\text { symptomatic mav aet supportive treatment }\end{array}$ & Yes & 367 & 89.7 \\
\hline
\end{tabular}

symptomatic may get supportive treatment 


\begin{tabular}{|c|c|c|c|}
\hline Variables & Responses & Frequency & $\begin{array}{l}\text { Percent } \\
(\%)\end{array}$ \\
\hline & No & 29 & 7.1 \\
\hline & $\begin{array}{l}\text { I don't } \\
\text { know }\end{array}$ & 13 & 3.2 \\
\hline \multirow{3}{*}{$\begin{array}{l}\text { All persons should wear general medical masks to prevent the } \\
\text { infection by Corona virus }\end{array}$} & Yes & 365 & 89.2 \\
\hline & No & 39 & 9.5 \\
\hline & $\begin{array}{l}\text { I don't } \\
\text { know }\end{array}$ & 5 & 1.2 \\
\hline \multirow{3}{*}{$\begin{array}{l}\text { To prevent the infection by COVID-19, individuals should avoid } \\
\text { going to crowded areas }\end{array}$} & Yes & 277 & 67.7 \\
\hline & No & 126 & 30.8 \\
\hline & $\begin{array}{l}\text { I don't } \\
\text { know }\end{array}$ & 6 & 1.5 \\
\hline \multirow{3}{*}{$\begin{array}{l}\text { To mitigating the spread of the virus, isolation and supportive } \\
\text { treatment for people who are infected with COVID-19 is } \\
\text { important }\end{array}$} & Yes & 390 & 95.4 \\
\hline & No & 14 & 3.4 \\
\hline & $\begin{array}{l}\text { I don't } \\
\text { know }\end{array}$ & 5 & 1.2 \\
\hline \multirow{3}{*}{$\begin{array}{l}\text { People who have contact with someone infected with COVID- } \\
19 \text { should be quarantined for } 14 \text { days }\end{array}$} & Yes & 393 & 96.1 \\
\hline & No & 9 & 2.2 \\
\hline & $\begin{array}{l}\text { I don't } \\
\text { know }\end{array}$ & 7 & 1.7 \\
\hline
\end{tabular}

\section{Attitude toward corona virus - 19 among residents in Mizan Aman town in July 2020}

More than half of the respondent $262(64.1 \%)$ agreed that COVID- 19 will be finally be successfully controlled. But, still high percentages of the respondents (28.4\%) did not agree COVID- 19 will be finally be successfully controlled. and $7.6 \%$ of the respondents are not sure if COVID- 19 will be finally be successfully controlled. And also more than half of respondents $263(64.3 \%)$ had confidence that Ethiopia can win the battle and $143(35.0 \%)$ had no such confidence and $3(0.7 \%)$ felt difficulty of deciding, seventy eight percent of the study participants agreed that it is important to keep their distance from others to avoid covid - 19 spreading, whereas $4.6 \%$ confused the importance of keeping distance from others to prevent COVID-19 spreading. The study participant agreed to go quarantine if infected was $70.6 \%$ but above a quarter did not agree to do so. Above $80 \%$ agreed travelers from abroad should be quarantined. Only $5.6 \%$ of the participants are not sure if whether travellers from abroad should be quarantined. (Table 3). 
Table 3

Attitude toward corona virus 19 among residents in Mizan Aman town in July 2020 ( $n=409)$

\begin{tabular}{|c|c|c|c|}
\hline Variables & Responses & Frequency & $\begin{array}{l}\text { Percent } \\
\text { (\%) }\end{array}$ \\
\hline \multirow{3}{*}{$\begin{array}{l}\text { Do you agree that COVID-19 will finally be successfully } \\
\text { controlled? }\end{array}$} & Agree & 262 & 64.1 \\
\hline & Disagree & 116 & 28.4 \\
\hline & Not sure & 31 & 7.6 \\
\hline \multirow{3}{*}{$\begin{array}{l}\text { Do you have confidence that Ethiopia can win the battle } \\
\text { against the COVID? }\end{array}$} & Yes & 263 & 64.3 \\
\hline & No & 143 & 35.0 \\
\hline & Not sure & 3 & 0.7 \\
\hline \multirow{3}{*}{$\begin{array}{l}\text { It is important to keep my distance from others, to avoid } \\
\text { spreading CoV-19 }\end{array}$} & Agree & 319 & 78 \\
\hline & Dis agree & 71 & 17.3 \\
\hline & Not sure & 19 & 4.6 \\
\hline \multirow{3}{*}{$\begin{array}{l}\text { To protect myself from COVID-19 exposure, I should stay } \\
\text { home if I am sick, unless I am receiving medical care. }\end{array}$} & Agree & 309 & 75.5 \\
\hline & Dis agree & 72 & 17.6 \\
\hline & Not sure & 28 & 6.8 \\
\hline \multirow[t]{3}{*}{ Would you like to go under quarantine if infected } & Agree & 289 & 70.6 \\
\hline & Dis agree & 106 & 25.9 \\
\hline & Not sure & 14 & 3.4 \\
\hline \multirow[t]{3}{*}{ Should travellers coming from abroad be quarantined } & Agree & 334 & 81.7 \\
\hline & Dis agree & 51 & 12.5 \\
\hline & Not sure & 24 & 5.9 \\
\hline
\end{tabular}

\section{Behavior toward corona virus 19 among residents in Mizan Aman town in July 2020}

More than half of the respondents 263 (64.3\%) were visited the crowded place during the interview and those didn't wear masks when leaving home were 250 (61.1\%), more than half (50.8\%) of the respondents did not avoid cultural behaviours, such as shaking hands, only $48.4 \%$ have been practiced social distancing and nearly half (46.2\%) of them did not wash their hands frequently with soap and water for at least 20 seconds. Almost all (96\%) did not meet international travellers.(Table 4). 
Table 4

Behavior toward corona virus 19 among residents in Mizan Aman town in July $2020(n=409)$

\begin{tabular}{|c|c|c|c|}
\hline Variables & Responses & Frequency & $\begin{array}{l}\text { Percent } \\
\text { (\%) }\end{array}$ \\
\hline \multirow{2}{*}{$\begin{array}{l}\text { Does the respondent found at public crowded place during } \\
\text { conducting this interview }\end{array}$} & Yes & 146 & 35.7 \\
\hline & No & 263 & 64.3 \\
\hline \multirow[t]{2}{*}{ Does the respondent worn a mask while leaving his/her home } & Yes & 159 & 38.9 \\
\hline & No & 250 & 61.1 \\
\hline \multirow{2}{*}{$\begin{array}{l}\text { Have you recently avoided cultural behaviours, such as } \\
\text { shaking hands? }\end{array}$} & Yes & 201 & 49.14 \\
\hline & No & 208 & 50.86 \\
\hline \multirow[t]{2}{*}{ Have you been practicing social distancing? } & Yes & 198 & 48.4 \\
\hline & No & 211 & 51.6 \\
\hline \multirow{2}{*}{$\begin{array}{l}\text { Recently, have you frequently washed your hands with soap } \\
\text { and water, for at least } 20 \text { seconds, especially after going to a } \\
\text { public place, or after nose-blowing, coughing, or sneezing? }\end{array}$} & Yes & 220 & 53.8 \\
\hline & No & 189 & 46.2 \\
\hline \multirow[t]{2}{*}{ Met people with recent international travel history } & Yes & 393 & $96 \%$ \\
\hline & No & 16 & $4 \%$ \\
\hline
\end{tabular}

\section{Discussion}

The knowledge level of the respondent about symptoms of COVID-19 is high that is, $94.9 \%$ of the respondents correctly answered that fever, fatigue, Dry cough and muscle ache can be one of the symptoms, $74.8 \%$ of the respondents correctly answered that, stuffy nose, runny nose, and sneezing are additional symptoms of corona virus. This finding was similar with study done in china where the knowledge level of the respondents was from $70.2-98.6 \%$.

Higher knowledge was also reported according to research conducted from Cameroon (14) the higher level of knowledge developed most probably due to government concern and awareness creation activities during the outbreak periods. We found that $75.1 \%$ of respondents correctly know that the disease is transmitted through contacting or eating wild animals and $82.6 \%$ believed that the disease transmission can occur through respiratory droplets. This knowledge level of our study participants was slightly lower than study reports from Cameroon where $94.3 \%$ knew that the disease could be transmitted by droplets when an infected person coughs, sneezes or speaks, $75.6 \%$ said through kissing infected person, $74.7 \%$ through a handshake, $88.3 \%$ through touching a contaminated surface and then touching your eyes, nose or mouth. This result showed that efforts should still be geared by concerning bodies to increase awareness about the ways of the disease transmissions. 
According the finding, $64.3 \%$ had confidence that Ethiopia can win the battle. This was in contrary with research report from china, where the confidence level was $97.1 \%(1)$. The difference in confidence level may be as a result of differences in applying preventive measures of the disease. The study participants who had optimistic attitude weather they go quarantine if infected were $70.6 \%$.this was higher than that of Pakistan which was $62 \%$.

The study result showed that $64.3 \%$ visited the crowded place during the interview and $61.1 \%$ didn't wear masks when leaving home, $50.8 \%$ of the respondents did not avoid cultural behaviours, such as shaking hands, only $48.4 \%$ have been practiced social distancing and nearly half $(46.2 \%)$ of them did not wash their hands frequently with soap and water for at least 20 seconds. The finding was conflicting with findings of china (1). This may implicate the communities are imprecisely practicing preventive measures and may highly disseminates the disease to the societies.

\section{Conclusion}

The knowledge level in Mizan Aman town was high and they had optimistic attitude, but the behaviors to prevent the disease transmission methods is low and this will increase the communication throughout the communities abruptly if immediate measures did not taken.

\section{Declarations}

\section{Ethics approval and consent to participate}

This research was conducted after getting approval from Mizan Aman Health Science College research and publication office. Permission was obtained from Mizan Aman town Trade and Industry Office. During data collection the aim of the study was communicated to the respondents and the food \& drink establishment owners after signing on the consent form

\section{Consent for publication}

The finding of this study was presented to Mizan Aman Health Science College.Moreover; attempts will be made to publish reputable international journals.

\section{Availability of data and materials}

The data that support the findings of this study is available at the hands of Mr. AM, the corresponding author and it can be delivered to the journal based on request at any time.

\section{Competing interests}


The authors declare that they have no competing interests.

\section{Funding}

The research was funded by Mizan Aman health science collage. The funders did not participated in any other activities

\section{Authors' contributions}

GM and WA, analyzing the data, drafting the manuscript, reviewing, AM and MG data entering, data cleaning, reviewing and editing

\section{ACKNOWLEDGEMENT}

First of all our special thanks go to God for his mercy for everything he has provided for us and his allowing finishing our works

Next we would like to thank Mizan Aman Health Science College for providing budget and other materials to successfully conduct our research and our gratitude go to Mizan Aman town administrative office for their collaboration by giving the necessary support

We also want to appreciate the study participants and data collectors,

\section{Authors' details}

1. Mizan Tepi university collage of medical and health science Department of nursing

2. Department of public Health Mizan Aman Health Science Collage

\section{References}

1. Zhong, B.-L., et al., Knowledge, attitudes, and practices towards COVID-19 among Chinese residents during the rapid rise period of the COVID-19 outbreak: a quick online cross-sectional survey. International journal of biological sciences, 2020. 16(10): p. 1745.

2. Laurencin, C.T. and A. McClinton, The COVID-19 pandemic: a call to action to identify and address racial and ethnic disparities. Journal of racial and ethnic health disparities, 2020: p. 1-5.

3. Van Bavel, J.J., et al., Using social and behavioural science to support COVID-19 pandemic response. Nature Human Behaviour, 2020: p. 1-12. 
4. Nkengasong, J.N. and W. Mankoula, Looming threat of COVID-19 infection in Africa: act collectively, and fast. The Lancet, 2020. 395(10227): p. 841-842.

5. Wilkinson, A., et al., Engaging 'communities': anthropological insights from the West African Ebola epidemic. Philosophical Transactions of the Royal Society B: Biological Sciences, 2017. 372(1721): p. 20160305.

6. Martinez-Alvarez, M., et al., COVID-19 pandemic in west Africa. The Lancet Global Health, 2020. 8(5): p. e631-e632.

7. 8. Baye, K., COVID-19 prevention measures in Ethiopia: Current realities and prospects. Vol. 141. 2020: Intl Food Policy Res Inst.

8. Akalu, Y., B. Ayelign, and M.D. Molla, Knowledge, attitude and practice towards COVID-19 among chronic disease patients at Addis Zemen Hospital, Northwest Ethiopia. Infection and drug resistance, 2020. 13: p. 1949.

9. Shigute, Z., et al., Containing the spread of COVID-19 in Ethiopia. Journal of global health, 2020. 10(1).

10. Azlan, A.A., et al., Public knowledge, attitudes and practices towards COVID-19: A cross-sectional study in Malaysia. Plos one, 2020. 15(5): p. e0233668.

11. Hussain, l., et al., Knowledge, Attitude, and Practices Toward COVID-19 in Primary Healthcare Providers: A Cross-Sectional Study from Three Tertiary Care Hospitals of Peshawar, Pakistan. Journal of community health, 2020: p. 1-9.

12. Afzal M.S et al Community-Based Assessment of Knowledge, Attitude, Practices and Risk Factors Regarding COVID-19 among Pakistanis ResidentsDuring a Recent Outbreak: A Cross-Sectional Survey. Journal of Community Health,20 20

13. Al-Hanawi M.K et al, Knowledge, Attitude and Practice toward COVID-19 among the Public in the Kingdom of Saudi Arabia: A Cross-Sectional Study. Frontiers in Public Health2020

14. Ngwewondo A. Knowledge, attitudes, practices of/towards COVID 19 preventive measures and symptoms: A cross-sectional study during the exponential rise of the outbreak in Cameroon 